\title{
Altered binding of the AP-1 protein on a negative regulatory element of $c-m y c$ is correlated with the progression of the malignancy of the lung and may contribute to c-myc expression
}

\author{
A.G. ELIOPOULOS ${ }^{1,2}$ and D.A. SPANDIDOS ${ }^{1,2}$ \\ ${ }^{1}$ Institute of Biological Research and Biotechnology, National Hellenic Research Foundation, Athens; \\ ${ }^{2}$ Medical School, University of Crete, Heraklion, Crete, Greece
}

Received July 19, 1993; Accepted September 2, 1993

\begin{abstract}
The binding activity of the AP-1 (FOS/JUN) complex to a negative regulatory element on the c-myc promoter was investigated in 7 tumour- versus normal lung specimens and it correlated with c-myc expression. AP-1 levels were found elevated in two samples representing stage I progression of the disease, while in three stage III tumour samples, the AP-1 binding activity was equal or slightly elevated compared with their normal adjacent tissue. Southern blot analysis revealed amplified c-myc in all three cases of stage III tumours. These results suggest that there is a negative correlation between FOS/JUN binding on c-myc promoter and the expression of c-myc during the progression of the disease, further supporting the fundamental role of AP-1 on c-myc regulation.
\end{abstract}

\section{Introduction}

The c-myc proto-oncogene encodes for two highly conserved nuclear phosphoproteins p62 and p64 involved in cellular proliferation and differentiation (1). Alteration of c-myc expression, due to proviral insertion, chromosomal translocation and gene amplification, leads to quantitative and/or qualitative changes in c-MYC protein and has been correlated with the development of several types of malignancies in a wide range of species (2). Particularly in humans, chromosomal translocations involving the c-myc and the immunoglobulin heavy and light chain genes has been directly related to the development of Burkitt's lymphomas (3), while amplification of c-myc has been observed in several cases in lung, breast and head and neck cancer (reviewed in ref. 4). Furthermore, the expression of c$m y c$ has been found elevated in stomach, colorectal and cervical cancer (4) and in agressive myelomas (5).

Correspondence to: Professor D.A. Spandidos, Institute of Biological Research and Biotechnology, National Hellenic Research Foundation, 48 Vas. Constantinou Ave., 11635 Athens,. Greece

Key words: FOS/JUN binding activity, c-myc oncogene, lung cancer
The regulation of c-myc expression is complex and is controlled not only at the level of transcription, by both positive and negative $c i s$-acting regulatory elements, but also at the post-transcriptional level (1).

The c-fos oncogene is known to participate in transcriptional regulation through formation of a c-fos:c-jun heterodimer protein known as the AP-1 complex (for a review see ref. 6). The AP-1 complex has been reported to participate in the process of differentiation $(7,8)$ and may also control the expression of genes involved in cellular proliferation (6). Recently, Hay et al found a Negative Regulatory Element (NRE) within the c-myc promoter region which contains an AP-1 binding site (9). Herein we report on the AP-1 binding activity from tumour and adjacent normal lung specimens to the NRE of $c-m y c$, as a possible mechanism or part of a mechanism regulating c-myc expression in lung cancer.

\section{Materials and methods}

Tissue specimens and cell lines. Tumour and adjacent normal lung tissue specimens were obtained from patients who had undergone lung surgery at the Metaxa Hospital, Pireas, Greece. None of these patients had previously received any chemotherapy. The histopathological type, the stage of differentiation and the pTNM of tumour of lung cancer patients are given in Table I.

The HeLa cell line used in this study, was continuously maintained in RPMI-1640 (Gibco) with $50 \mu \mathrm{g} / \mathrm{ml}$ streptomycin and $300 \mu \mathrm{g} / \mathrm{ml}$ penicillin, supplemented with $10 \%$ fetal calf serum (Flow), at $37^{\circ} \mathrm{C}$ in a $5 \% \mathrm{CO}_{2}$ atmosphere.

Preparation of nuclear extracts. Nuclear extracts from tissue specimens were prepared as previously described (8). Briefly, tissues were cut into pieces, homogenised with a Btype Dounce homogenizer in hypotonic buffer $(25 \mathrm{mM}$ TrisHCl, pH 7.5, $5 \mathrm{mM} \mathrm{KCl}, 0.5 \mathrm{mM} \mathrm{MgCl} 2,0.5 \mathrm{mM}$ dithiothreitol (DTT) and $0.5 \mathrm{mM}$ PMSF), centrifuged at $2,000 \times \mathrm{g}$, washed three times with isotonic buffer $(25 \mathrm{mM}$ TrisHCl, pH 7.5, $5 \mathrm{mM} \mathrm{KCl}, 0.5 \mathrm{mM} \mathrm{MgCl}_{2}, 0.1 \mathrm{M}$ sucrose, $0.5 \mathrm{mM}$ DTT and $0.5 \mathrm{mM}$ PMSF), and resuspended in nuclei extraction buffer $(25 \mathrm{mM}$ TrisHCl, $\mathrm{pH} 7.5,1 \mathrm{mM}$ EDTA, $0.1 \%$ Triton X-100, $0.5 \mathrm{mM}$ DTT, $0.5 \mathrm{mM}$ PMSF 


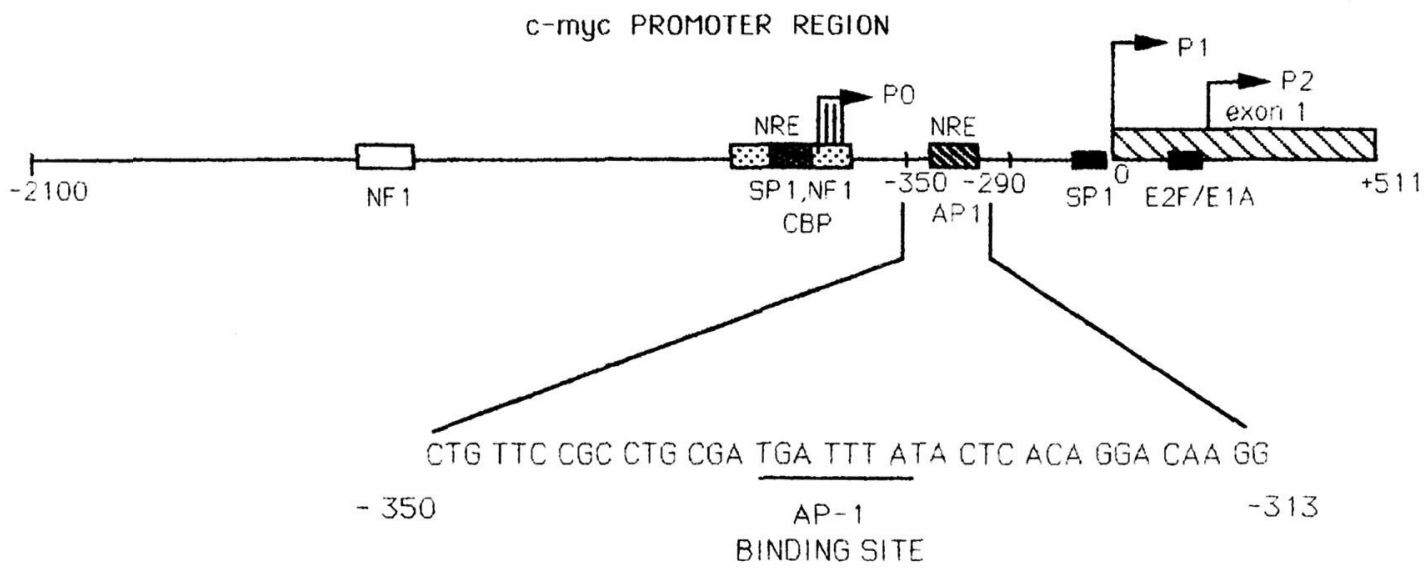

Figure 1. Regulatory elements and transcription factor binding sites on the c-myc promoter. The AP-1 binding site is located whithin an NRE domain of c-myc promoter (9).

Table I. pTNM, stage of differentiation and histopathological type of tumour of lung cancer patients.

\begin{tabular}{llll}
\hline Patient no. & pTNM & $\begin{array}{l}\text { Stage of } \\
\text { differentiation }\end{array}$ & $\begin{array}{l}\text { Histopathological } \\
\text { type of lung tumour }\end{array}$
\end{tabular}

\begin{tabular}{llll}
\hline 1 & T2N1M0 & II & adenocarcinoma \\
2 & T3N0M0 & III & squamous \\
3 & T2N1M0 & II & SCLC \\
4 & T3N1M0 & III & squamous \\
5 & T2N0M0 & I & squamous \\
6 & T1N0M0 & I & adenocarcinoma \\
7 & T3N2M0 & III & SCLC \\
\hline
\end{tabular}

and $0.6 \mathrm{M} \mathrm{KCl}$ ). The nuclei were inverted slowly for $30 \mathrm{~min}$ and the extract clarified by centrifugation at $2.5 \times 10^{4} \mathrm{~g}$ for 60 min at $4^{\circ} \mathrm{C}$. Nuclear extracts were stored at $-70^{\circ} \mathrm{C}$. Protein estimation was performed at $595 \mathrm{~nm}$ using the Biorad Protein Assay (Biorad).

Synthesis of oligonucleotides and gel retardation assays. The mycAP-1 oligonucleotide 5'-CCTGCGATGATTTATACTC ACAGG-3' contains the AP-1 binding site of the NRE domain of the human c-myc promoter (-342 to -313) (9) (Fig. 1). The $\mathrm{E}_{3} \mathrm{AP} 1$ oligonucleotide 5'-CCGAAGTTCAGAT GACTA ACTCAGGG-3' representing the region between nucleotides -81 and -103 of the EIA inducible $E_{3}$ promoter (10) containing an AP-1 binding site, was used for competition experiments. Both oligonucleotides were synthesized on an Applied Biosystems 381A DNA synthesizer.

Single stranded complementary oligonucleotides were annealed, end-labelled using $\gamma^{-32} \mathrm{P}$-ATP (Amersham) and T4 polynucleotide kinase (Boehringer) and run on an $8 \%$ polyacrylamide gel to test the annealing.

The binding reaction mixture contained $10 \mathrm{mM}$ Hepes (pH 7.9), 0.2 mM EDTA, $94 \mathrm{mM} \mathrm{NaCl}, 0.1 \mathrm{mM}$ PMSF, 0.1 $\mathrm{ng} / \mathrm{ml} \mathrm{BSA}, 4 \%$ glycerol, $3 \mu \mathrm{g}$ poly(dI-dC) (Pharmacia), 0.2$1.0 \mathrm{ng}{ }^{32} \mathrm{P}$-labelled DNA and $20 \mu \mathrm{g}$ nuclear extracts (except when otherwise indicated). The reaction mixture was left on ice for $30 \mathrm{~min}$. Then, reaction mixtures were loaded onto a $5 \%$ polyacrylamide gel (29:1 acrylamide: N,N'-methylene bisacrylamide, Serva). Gels were run at $4^{\circ} \mathrm{C}$ in $0.55 \mathrm{X}$ TBE, dried and exposed to X-ray film for autoradiography (Fuji).

The rabbit monoclonal antibody FOS 388 used in this study was a generous gift of Dr D.A.F. Gillespie (Beatson Institute for Cancer Research, Glasgow, UK).

Extraction of DNA and Southern blot analysis. DNA extracts from tissue specimens were prepared as described by Sambrook et al (11), slightly modified as follows: after the isolation of nuclear proteins as described above, the debris, which contained the cellular DNA, was incubated $\mathrm{O} / \mathrm{N}$ in lysis solution (10 mM EDTA, $10 \mathrm{mM}$ TrisHCl, $\mathrm{pH} 7.8,150$ $\mathrm{mM} \mathrm{NaCl}, 0.5 \%$ SDS and $100 \mu \mathrm{g} / \mathrm{ml}$ proteinase-K) at $37^{\circ} \mathrm{C}$. After two phenol/chloroform/ isoamylalcohol extractions, the aqueous phase was removed and incubated for $2 \mathrm{~h}$ with 100 $\mu \mathrm{g} / \mathrm{ml}$ pancreatic $\mathrm{RNase}$ (Sigma) at $37^{\circ} \mathrm{C}$ and for an additional $2 \mathrm{~h}$ period with $100 \mu \mathrm{g} / \mathrm{ml}$ proteinase-K (Boehringer) followed by phenol/ chloroform/isoamylalcohol extraction twice. The aqueous phase was then removed and the DNA was precipitated with ethanol. The DNA was washed with $70 \% \mathrm{EtOH}$, dried briefly, resuspended in sterile water and estimated photometrically at $260 \mathrm{~nm}$ using an LKB 4054 spectro-photometer.

$10 \mu \mathrm{g}$ of each DNA sample was digested $\mathrm{O} / \mathrm{N}$ with $100 \mathrm{U}$ of HindIII (Boehringer), precipitated with ammonium acetate and ethanol, dried briefly and resuspended in $20 \mu \mathrm{l}$ of sterile water. Samples were then loaded on a $0.7 \%$ agarose gel and run $\mathrm{O} / \mathrm{N}$ at $30 \mathrm{~V}$ in $1 \mathrm{X}$ TBE running buffer.

For Southern blotting we followed the Hybond ${ }^{-}{ }^{+}$ protocol (Amersham) using $20 \mathrm{X}$ SSPE buffer for transfer. After blotting, DNA was fixed by baking the membrane at $80^{\circ} \mathrm{C}$ for $2 \mathrm{~h}$

Pre-hybridization with $5 \mathrm{X}$ SSPE, $5 \mathrm{X}$ Denhardt's solution, $50 \%$ formamide and $0.5 \%(\mathrm{w} / \mathrm{v})$ SDS for $6 \mathrm{~h}$ in $42^{\circ} \mathrm{C}$, was followed by overnight hybridization. The probes used were the the $1.4 \mathrm{~Kb} \mathrm{ClaI} / E c 0 R I$ fragment of plasmid pMC41-3RC, carrying the third exon (EIII) of the human c$m y c$ gene (12) and the $6.4 \mathrm{~Kb} \mathrm{BamHI} / \mathrm{BamHI}$ fragment of plasmid pHo6N1, carrying the human H-ras gene (13). 
a

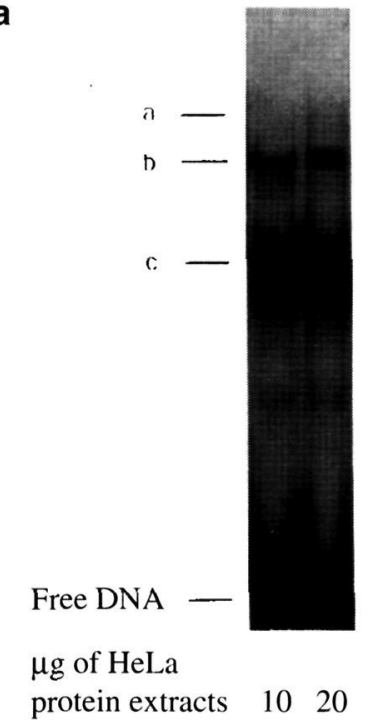

PROBE $\quad m y c A P-1$

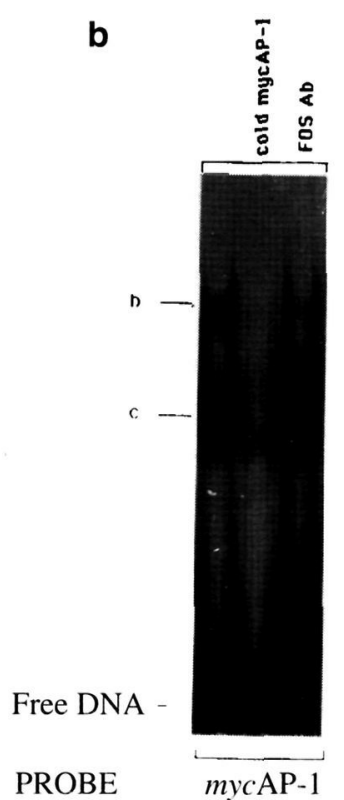

Figure 2. (a) Binding of nuclear factors from HeLa cells to mycAP-1 oligo. Only the $b$ complex has been shown to be a FOS/JUN (AP-1) protein (see text). (b) Effect of FOS antibody (lane 2) and mycAP-1 cold competitor (lane 3) on c-myc DNA-protein complexes in a gel retardation assay. Extracts from HeLa cells were used.

DNA-inserts were labelled with ${ }^{32} \mathrm{P}$ dCTP (Amersham) using the random primed DNA labelling kit of Boehringer Mannheim.

Membranes were finally washed twice in $2 \mathrm{X}$ SSPE, $0.1 \%$ SDS in room temperature for $30 \mathrm{~min}$, twice in $1 \mathrm{X}$ SSPE, $0.1 \% \mathrm{SDS}$ for $20 \mathrm{~min}$ at $42^{\circ} \mathrm{C}$ and once in $0.5 \mathrm{X} \mathrm{SSPE}, 0.1 \%$ SDS at $42^{\circ} \mathrm{C}$ for $15 \mathrm{~min}$, followed by exposure to X-ray film (Fuji) with an intensifying screen.

\section{Results}

The NRE of c-myc is located in position -350 to -290 relative to transcription start site P1 and has been reported to contain the recognition site for the cellular transcription factor AP-1 (ref. 9 and Fig. 1).

When crude extracts from HeLa cells, which are known to overexpress the FOS/JUN heterodimer protein, are incubated with the mycAP-1 oligonucleotide, three complexes a, b and $\mathrm{c}$ are formed (Fig. 2a and ref. 9). Only the b-complex has been shown to represent the FOS/JUN protein (9). Indeed, antibody against the FOS protein eliminated the b-band in extracts from both HeLa cells (Fig. 2b, lane 3) and lung tumour specimen no. 3 (Fig. 3a, lane 2). In order to test further the specificity of the binding, we performed competition assays with excess $(200 \mathrm{x})$ of mycAP- 1 and $\mathrm{E}_{3} \mathrm{AP}-1$ cold oligonucleotides. Excess of cold mycAP-1 inhibited the binding of protein-DNA complexes $b$ and $c$ in both the HeLa cells (Fig. 2b, lane 2) and in the protein extracts from specimen no. 3 (Fig. 3b, lane 3), while cold $\mathrm{E}_{3} \mathrm{AP}-1$ inhibited mainly the formation of complex b (Fig. 3b, lane 4).

By performing gel retardation assays with nuclear extracts from tumour and adjacent normal lung specimens, we observed an altered AP-1 binding to the c-myc NRE. a
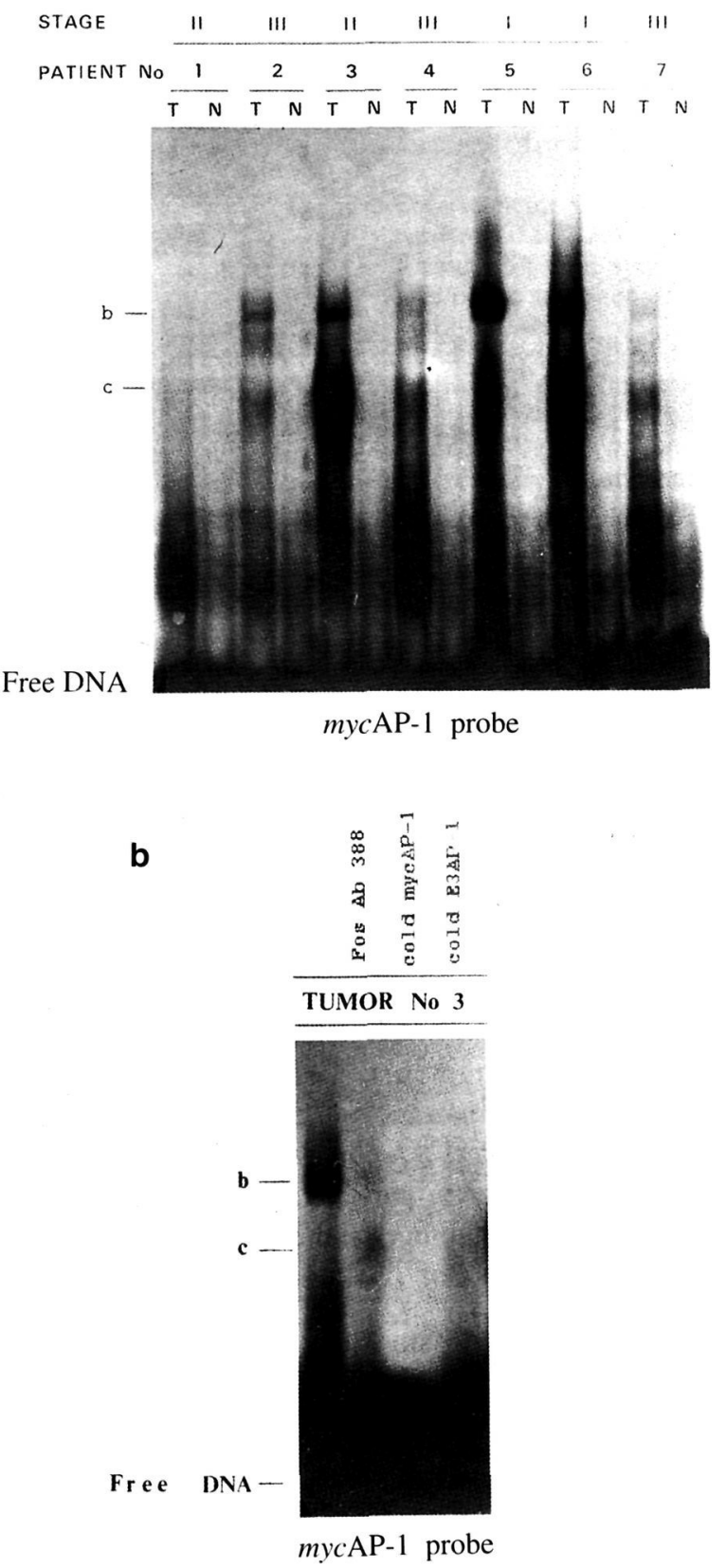

Figure 3. (a) Gel retardation assay with extracts from tumour and adjacent normal lung tissue. (b) Effect of FOS antibody (lane 2) and excess of cold mycAP-1 and $\mathrm{E}_{3} \mathrm{AP}-1$ (lanes 3 and 4) on c-myc DNA-protein complexes in gel retardation assay. Extracts from tumour specimen no. 3 were used.

Elevated AP-1 levels were observed in two stage I tumours (Fig. 3a, samples 5, 6), while in the three stage III tumours, the AP-1 levels were equal or slightly elevated compared with the normal tissue (Fig. 3a, samples 2, 4 and 7). The latter three specimens revealed amplified c-myc in Southern blot analysis (Fig. 4, lanes 2,4,7). One of the two stage II lung tumours presented low AP-1 levels, while in the other, the AP-1 activity, although elevated, was lower than that of the stage I tumours (Fig. 3a, samples 1 and 3).

\section{Discussion}

The role of the $c-m y c$ oncogene in the progression of carcinogenesis has been extensively investigated in a range 


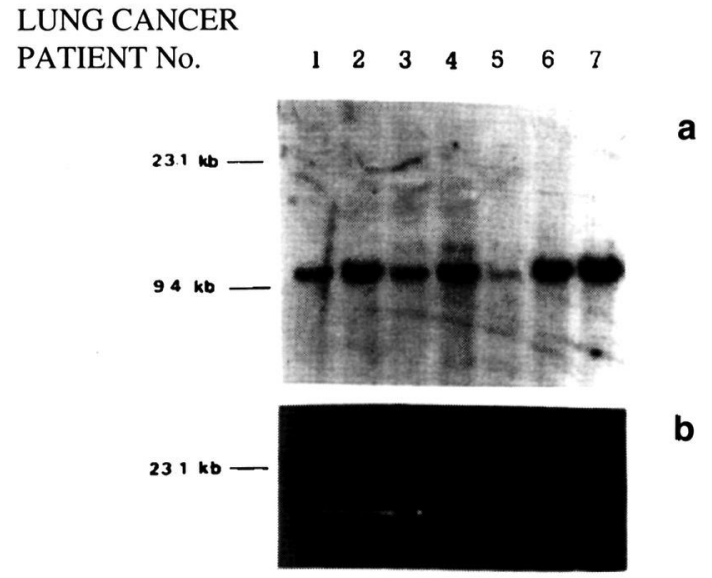

Figure 4. Southern blot analysis revealed c-myc amplification in three stage III samples (samples 2,4,7). $10 \mu \mathrm{g}$ of DNA from cases 1-7 was digested with HindIII and analyzed with (a) c-myc exon 3 probe and (b) c-H-ras probe. The same filter was used for the two hybridizations. Autoradiographic exposure time was approximately 4 days. Lambda phage DNA, digested with HindIII, was used as a molecular weight marker. Densitometric analysis of the autoradiograph, normalized to H-ras, which is known not to be amplified in lung tumours (24), revealed three samples (patient numbers 2,4 and 7) with c-myc levels at least twice those of H-ras.

of human solid tumours. Genetic alterations of $c-m y c$ is believed to be important in the progression of these cancers and may be of use as a prognostic indicator (4).

In lung cancer in particular, amplified c-myc has been found in primary tumours and cell lines $(14,15)$ and has been correlated with poor prognosis (16). Understanding the mechanism of c-myc regulation in these cases is of great importance.

The modulation of c-myc expression is complicated and is accomplished on both transcriptional and post-transcriptional level. The c-myc NRE, located within the c-myc promoter region (Fig. 1), participates in the modulation of the oncogene expression through binding of three transcription factors $(8,9)$. One of them (complex b, Figs. 2 and 3 ) is the heterodimer protein FOS/JUN (AP-1). That NRE has been shown to be important for c-myc expression following platinum and anthracycline exposure of Friend cells $(17,18)$, while the altered FOS/JUN binding activity we have recently reported, during the HMBA-induced differentiation of mouse erythroleukemic cells (8), further supports the contribution of the AP-1 protein to c-myc regulation.

In this study, we performed gel retardation assays with protein extracts from lung tumour and adjacent normal tissue, to examine the AP-1 levels bound to the c-myc NRE and correlated these results with c-myc expression.

We found elevated FOS/JUN levels in only three out of seven samples, that is two stage I and one stage II lung tumours, while in the other four samples the AP-1 activity was equal or slightly elevated compared with the normal tissue. Three of the latter cases corresponded to stage III tumours and presented amplified c-myc, as revealed by Southern blot analysis (Fig. 4). Therefore, a good correlation between stage of differentiation and AP-1 binding activity exist on c-myc NRE; the higher the stage, the lower the FOS/JUN levels bound to that region. Recently, Linardopoulos et al, using the same model of lung cancer, showed an opposite pattern of AP-1 binding to an AP-1-like site in the promoter region of retinoblastoma $(\mathrm{Rb})$ gene (19). In that study, the increased binding was in accordance with the development of tumour differentiation. It is therefore possible that the transcription factor AP-1 plays a different role in the expression of $\mathrm{Rb}$ and $\mathrm{c}-m y c$ during progression of the malignancy of the lung.

The expression of the c-myc gene is considered to be crucial in cellular proliferation (20); lymphocytes stimulated with mitogens rapidly increased their expression of c-myc mRNA as they entered into cell cycle (21), while the c-MYC protein has been shown to bind to an autonomously replicating sequence (ARS) in eukaryotic cells and thus promoting its replication (22). There is also evidence of high proliferative activity in stage III myeloma cells in agressive myeloma with overexpression of $c-m y c(5,23)$. Taking into account these reported experimental data, our results suggest that the low levels of AP-1 bound to the NRE of c-myc could contribute to the induction of $c-m y c$ expression and also to the proliferative activity which is characteristic of the late stages of tumour development.

In conclusion, despite the small number of tumours tested, our results further support a role of the heterodimer protein AP-1 in tumour progression and also in transcriptional regulation of c-myc expression. It is suggested that the decreased levels of FOS/JUN bound to the c-myc NRE in high stages of tumour differentiation could contribute to the overexpression of the c-myc oncogene, which, in turn, could affect the cellular proliferative potential and clinical outcome.

\section{References}

1. Spencer CA and Groudine M: Control of c-myc regulation in normal and neoplastic cells. Adv Cancer Res 56: 1-43, 1991.

2. Cole MD: The myc oncogene: its role in transformation and differentiation. Ann Rev Genet 20: 361-384, 1986.

3. Adams J, Gerondakis S, Webb E, Corcoran LM and Cory S: Cellular myc oncogene is altered by chromosome translocation to the immunoglobulin locus in murine plasmacytomas and is rearranged similarly in human Burkitt lymphomas. Proc Natl Acad Sci USA 80: 1982-1986, 1983.

4. Field JK and Spandidos DA: The role of ras and myc oncogenes in human solid tumours and their relevance in diagnosis and prognosis. Anticancer Res 10: 1-22, 1990.

5. Nobuyoshi M, Kawano $M$, Tanaka $H$, Ishikawa $H$, Tanabe $O$, Iwato K, Asaoku H, Sakai A and Kuramoto A: Increased expression of the c-myc gene may be related to the aggressive transformation of human myeloma cells. Br J Haematol 77: 523-528, 1991.

6. Angel P and Karin M: The role of Jun, Fos and the AP-1 complex in cell proliferation and transformation. Biochim Biophys Acta 1072: 129-157, 1991.

7. Distel RJ, Ro HS, Rosen BS, Groves DL and Spiegelman BM: Nucleoprotein complexes that regulate gene expression in adipocyte differentiation: Direct participation of c-fos. Cell 49: 835-844, 1987.

8. Eliopoulos AG and Spandidos DA: Altered FOS/JUN binding activity on a negative regulatory element of c-myc during differentiation of mouse erythroleukemic cells. Int $\mathbf{J}$ Oncol 2 : 883-888, 1993.

9. Hay N, Takimoto M and Bishop JM: A Fos protein is present in a complex that binds a negative regulator of $m y c$. Gene Develop 3: 293-303, 1989. 
10. Hurst $\mathrm{HC}$ and Jones NC: Identification of factors that interact with the EIA-inducible adenovirus $\mathrm{E}_{3}$ promoter. Gene Develop 1: 1132-1146, 1987.

11. Sambrook J, Fritsch EF and Maniatis T: Analysis and cloning of eukaryotic genomic DNA. In: Molecular Cloning. A laboratory manual. 2nd Edition. Cold Spring Harbor Laboratory, 1989.

12. Dalla-Favera R, Wong-Staal $F$ and Gallo RC: Oncogene amplification in promyelocytic leukaemia cell line HL-60 and primary leukaemia cells of the same patient. Nature 299: 61-63, 1982.

13. Spandidos DA and Wilkie NM: Malignant transformation of early passage rodent cells by a single mutated human oncogene. Nature 310: 469-475, 1984.

14. Wong AJ, Ruppert JM, Eggleston J, Hamilton SR, Baylin SB, Vogelstein B: Gene amplification of c-myc and N-myc in small cell carcinoma of the lung. Science 233: 461-463, 1986.

15. Little CD, Nau MM, Carney DN, Gazdar AF, Minna JD: Amplification and expression of the c-myc oncogene in human lung cancer cell lines. Nature 306: 194-196, 1983.

16. Johnson BE, Ihde DC, Makuch RW, Gazdar AF, Carney DN, Oie H, Russel E, Nau MM and Minna JD: Myc family oncogene amplification in tumour cell lines established from small cell lung cancer patients and its relationship to clinical status and course. J Clin Invest 79: 1629-1634, 1987.

17. Eliopoulos AG, Kerr DJ and Spandidos DA: The effect of doxorubicin, daunorubicin and 4'-epidoxorubicin on the exogenous c-myc promoter in mouse erythroleukemia cells. Anticancer Res 11: 2153-2158, 1991.
18. Eliopoulos AG, Kerr DJ and Spandidos DA: The effect of cisplatin and carboplatin on c-myc promoter in erythroleukemic cells. Anti-Cancer Drugs 2: 597-601, 1991.

19. Linardopoulos S, Papadakis E, Delakas D, Cranidis A and Spandidos DA: Human lung and bladder carcinoma tumours as compared to their adjacent normal tissue have elevated AP-1 activity at the retinoblastoma gene promoter. Anticancer Res 13: 257-262, 1993.

20. Corry S: Activation of cellular oncogenes in hemopoietic cells by chromosome translocations. Adv Cancer Res 47: 189-234, 1986.

21. Kelly K, Cohran BH, Stiles CD and Leder P: Cell-specific regulation of the $c-m y c$ gene by lymphocyte mitogens and platelet-derived growth factor. Cell 35: 603-610, 1983.

22. Iguchi-Ariga SMM, Itani T, Kiji Y and Ariga H: Possible function of the c-myc product: promotion of cellular DNA replication. EMBO J 6: 2365-2371, 1987.

23. Greipp PR and Kyle RA: Clinical, morphological and cell kinetic differences among multiple myeloma, monoclonal gammopathy of undermined significance and smoldering multiple myeloma. Blood 72: 219-223, 1983.

24. Pulciani S, Santos E, Long LK, Sorrentino V and Barbacid M: Ras gene amplification and malignant transformation. Mol Cell Biol 5: 2836-2841, 1985. 